\title{
Barriers vs. bridges: Undocumented immigrants' access to post-secondary education in Ontario
}

Marietta Armanyous

Graham Hudson

RCIS Working Paper No. 2019/5

December 2019

SERIES EDITOR

Usha George

Ryerson Centre for Immigration \& Settlement Ryerson University Kerr Hall South, Room 46C 350 Victoria Street, Toronto, ON M5B2K3 http://www.ryerson.ca/rcis 


\title{
RCIS Working Paper
}

No. $2019 / 5$

\section{Barriers vs. bridges: Undocumented immigrants' access to post- secondary education in Ontario}

\author{
Marietta Armanyous \\ Ryerson University
}

Graham Hudson

Ryerson University

RCIS Working Papers present scholarly research of all disciplines on issues related to immigration and settlement. The purpose is to stimulate discussion and collect feedback. The views expressed by the author(s) do not necessarily reflect those of RCIS. For a complete list of RCIS publications, visit www.ryerson.ca/rcis

ISSN: 1929-9915 


\section{Table of Contents}

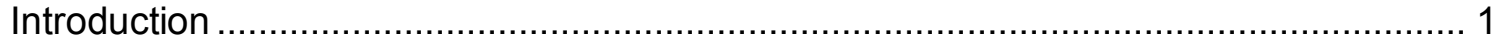

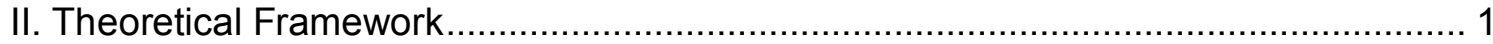

Human Right to Education.....................................................................................

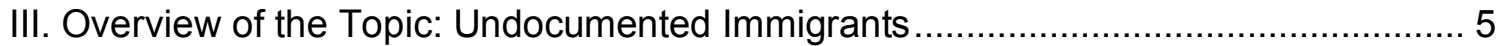

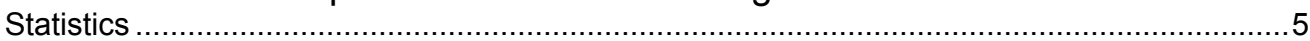

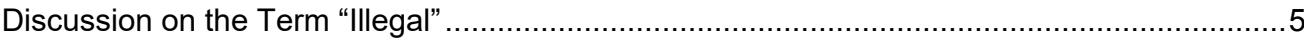

The Debate over Providing Access to Post-Secondary Education ......................................6

IV. Access Granted to Primary and Secondary Schools ............................................ 7

V. Barriers to Accessing Post-Secondary Education in Ontario, Canada ........................ 8

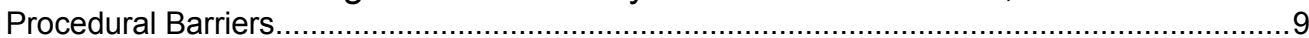

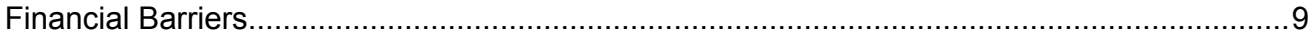

VI. The Canadian Initiative ................................................................................ 11

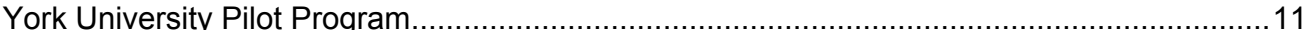

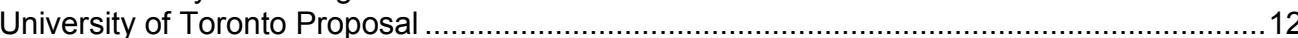

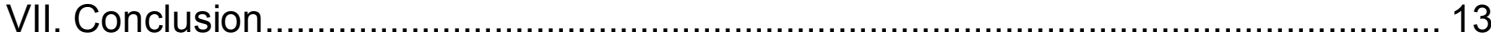

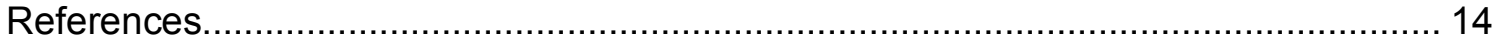




\section{Introduction}

The governance of migration and human mobility is a contentious matter, and it has only become more prominent in public, political, and legal spheres. One of the most challenging issues is how to protect and promote the rights of undocumented immigrants, who face multiple forms of legal and social exclusion. In the face of public pressure to control borders, governments must decide whether persons already living and working in cities, towns, and rural areas should be able to access public services, such as health and education. The question of education has become more prominent in the United States and Canada. The norm is for governments and schools to deny or outright exclude undocumented persons from accessing education, but this has been changing in certain jurisdictions, including sanctuary cities and states.

Canadian policies are also changing. Although access to education in publicly-funded institutions is currently a legal right for all residents of Ontario (subject to some qualifications unrelated to immigration status), attaining access remains a challenge for undocumented immigrants. Recently, activists have been pushing for a right to access higher education in universities and colleges. Even if not provided for in domestic law, access to education is a legal right under international law. The UN Commission on Human Rights notes that the right to education has a special function, in that it "unlocks other rights when guaranteed, while its denial leads to compounded denials of other human rights and perpetuation of poverty" (UN Commission on Human Rights, 2004, p. 7). Others describe education as an "empowerment right" (Kalantry, Getgen, \& Koh, 2010, p. 260; UN Committee on Economic, Social and Cultural Rights [CESCR], 1999).

This paper examines existing barriers that undocumented immigrants face if they wish to access post-secondary education in Ontario, Canada. It also addresses the policies that Canadian universities have implemented (or plan to implement) to remove these barriers, thereby allowing undocumented immigrants to obtain formal post-secondary education. It argues that access to higher education is a binding international human right and that provincial governments and universities should ensure access.

The primary questions that this research paper aims to address are the following:

- What are the legal, procedural, and/or financial barriers to accessing post-secondary education?

- Are provincial governments implementing policies to remove these barriers? If so, what are they?

- Are Canadian universities implementing policies to remove these barriers? If so, what are they?

By addressing key obstacles and identifying possible solutions, we can better advocate for appropriate policy changes. Whereas there is significant literature on this topic in the US, there is far less information in the Canadian context; it is an important matter to bring to the forefront of both Canadian immigration and education policy discussions. Since the constant threat of deportation serves as a silencing mechanism and form of political suppression, it is important to advocate with and, when necessary, on behalf of undocumented migrants. My research will help shed more light on this concern and amplify the need for governments/institutions to find pragmatic ways to resolve this issue.

\section{Theoretical Framework}

\section{Human Right to Education}

Due to the increasing securitization of immigration, a trend that has risen significantly 
in the post-9/11 era, immigrants experience restrictions not only on their basic political and civil rights, but on social human rights - under which education falls (Crépeau, Nakache, \& Atak, 2007, p. 311). This is particularly applicable to immigrants who are in even more precarious situations by having no legal status in the country where they reside.

This paper is guided by the human right to education as its theoretical framework. While this may be a contentious standpoint, education is arguably a basic human right. According to the United Nations Human Rights Office of the High Commissioner $(\mathrm{OHCHR})$, the rationale behind this notion is that "the right to education unlocks other rights when guaranteed, while its denial leads to compounded denials of other human rights and perpetuation of poverty" (UN Commission on Human Rights, 2004, p. 7). Essentially, one's access to education is necessary not only because it is a human right in and of itself, but also because it provides one with the ability to seek out other fundamental rights that are owed to them; education is an "empowerment right" (Kalantry, Getgen, \& Koh, 2010, p. 260; UN Committee on Economic, Social and Cultural Rights [CESCR], 1999).

This social human right implies that every individual has the right to access all levels of education. The Canadian Charter of Rights and Freedoms (1982) states, "Every individual is equal before and under the law and has the right to the equal protection and equal benefit of the law without discrimination ... based on race, national or ethnic origin, colour, religion, sex, age or mental or physical disability". This assertion implies that everyone is entitled to and cannot be denied basic human rights. The Supreme Court of Canada-the highest court in the Canadian justice system - was presented with a case regarding this matter, to which its decision strongly denounced discrimination and affirmed that all individuals have equal rights.

Social human rights were officially extended to non-citizens with the Supreme Court's 1989 ruling in Andrews v. Law Society of British Columbia. While immigrants are not directly mentioned as a group to which discrimination is not permitted, the Andrews v. Law Society of British Columbia (1989) case confirms this notion. To summarize the case, Mark David Andrews was a Canadian permanent resident who wished to be admitted into British Columbia's bar (also known as the Law Society of British Columbia) but was denied. The reason for his denial was because, while he met all of the other requirements, he was not a Canadian citizen. The Supreme Court of Canada ruled in favour of Andrews, validating the argument that one's citizenship status does not impede on one's rights under the Charter of Rights and Freedoms. In their decision, the Supreme Court judges state,

Section 15(1) of the Charter provides for every individual a guarantee of equality before and under the law, ...without discrimination. Discrimination is a distinction which, whether intentional or not but based on grounds relating to personal characteristics of the individual or group, has an effect which imposes disadvantages not imposed upon others or which withholds or limits access to advantages available to other members of society. Distinctions based on personal characteristics attributed to an individual solely on the basis of association with a group will rarely escape the charge of discrimination, while those based on an individual's merits and capacities will rarely be so classed (Andrews v. Law Society of British Columbia, 1989).

Even though this case addresses whether a Canadian permanent resident is able to access the same opportunities as a citizen, the Supreme Court's decision outlines the type of discrimination that is no longer allowed-discrimination based on one's characteristics. Since Andrews' issue was his permanent residency status in Canada, the ruling implies that one's legal status is a "personal characteristic" that cannot be used to discriminate against their ability to access opportunities that would otherwise be available to them. To that end, one could argue that an undocumented immigrant's legal status cannot deny 
them access to obtaining an education in Canada.

It is important to note, however, that cases with rulings not in favour of undocumented immigrants also exist. Unlike Andrews v. Law Society of British Columbia, in which undocumented immigrants' rights are validated through a case that involves a person with legal status, there are several cases that expressly deny non-status immigrant rights to equality. The Toussaint $v$. Canada (Attorney General) case is particularly relevant as it concerns an undocumented immigrant who was denied access to a social human righthealth. The appellant arrived in Canada in 1999 as a visitor, overstayed her visa, and continued to live and work in Canada. Upon becoming ill and wishing to seek additional treatment, the appellant attempted to access the Interim Federal Health Program (IFHP) to help cover her emergency medical care. The Federal Court of Appeals ruled against the appellant; it asserted that excluding her from accessing health coverage is permissible because the IFHP only applies to "legal entrants into Canada who are under immigration jurisdiction or for whom immigration authorities feel responsible" (Toussaint v. Canada [Attorney General], 2011). The judges decided that these categories do not apply to the appellant and, thus, her case was denied. The logic behind the court's decision refers to the appellant's "illegal" status when it contends, "Extending these benefits to all foreign nationals in Canada, even those in Canada illegally, stretches the program well beyond its intended purpose" (Toussaint v. Canada [Attorney General], 2011). Although court decisions favouring undocumented immigrants' human rights do indeed occur, decisions made directly against non-status immigrant appellants also exist. It is vital that both are discussed to temper the optimism that this paper may evoke if solely pro-immigrant court decisions were mentioned.

In addition to domestic legislation, international law has also been established to address the issue surrounding the right to education. Member states of the United Nations (UN) drafted the International Covenant on Economic, Social and Cultural Rights (ICESCR) on December 16, 1966; Canada signed and ratified the treaty on May 19, 1976 (UN General Assembly, n.d.). Signing an international treaty signifies that the nation agrees to the general terms of the agreement, and suggests an intention to ratify the treaty. The act of ratification officially binds a state to both comply with and implement each provision in a treaty. Ratification is a decision that is made on the basis of domestic political and legal considerations. In constitutional democracies, the executive and legislative branches of a federal government each have a role; this is the case in Canada, where the government, at the very least, tables a treaty before parliament for 21 days before ratification. As of 2018, 169 states have signed the ICESCR. Those who signed and ratified the ICESCR committed themselves to upholding various economic, social, and cultural rights - particularly labour rights, the right to education, the right to health, and the right to an overall adequate standard of living (UN General Assembly, 1966).

The ICESCR states that no individuals should be discriminated against and denied access to the human rights mentioned above-including education. Article 2(2) clearly notes that the parties signing the agreement "guarantee that the rights enunciated in the present Covenant will be exercised without discrimination of any kind as to race, colour, sex, language, religion, political or other opinion, national or social origin, property, birth or other status" (UN General Assembly, 1966). While the Covenant does not expressly state that one's immigration status should not be a barrier to access, this distinction arguably falls under the category of "other status" and, therefore, discrimination against this group should not be permitted. Ruth Gavison (2003), a law professor whose research includes human rights and the protection of minors, also makes this argument when she states, "Human rights are rights that 'belong' to every person, and do not depend on the specifics of the individual or the relationship between the right-holder and the right-grantor. Moreover, human rights exist irrespective of the question whether they are granted or recognized by the legal and social system within which we live. ... In other words, human rights are moral, pre-legal rights" (p. 25). Gavison's remarks support the claim that human 
rights are pre-political and should be granted regardless of one's legal status.

In Article 13(2), the ICESCR distinguishes between the various levels of schooling and specifies the rights to accessing each one. The primary level must be free and compulsory to all individuals; secondary and higher education, while not compulsory, "shall also be made equally accessible to all, ....in particular by the progressive introduction of free education" (UN General Assembly, 1966). While it may not be free immediately, the Covenant emphasizes that education must be made available and accessible to all.

The Committee on Economics, Social and Cultural Rights (CESCR) claims that the right to education has several essential features, including accessibility (CESCR, 1999). To that end, non-discrimination, economic accessibility, and physical accessibility are the three components of this feature, which a state must address to ensure that it abides by the Covenant (CESCR, 1999). At least two of the three components directly apply to all undocumented immigrants. Regarding one's accessibility to education without discrimination, CESCR stresses that "education must be accessible to all, especially the most vulnerable groups, in law and fact, without discrimination on any of the prohibited grounds" (CESCR, 1999). Providing access to education without financial barriers is another key issue that faces undocumented immigrants, alongside other socioeconomically marginalized groups. The CESCR asserts, "[E]ducation has to be affordable to all" (CESCR, 1999). Therefore, as the Covenant states, all levels of education should be free (Kalantry et al., 2010, p. 277; UN General Assembly, 1966). However, as the CESCR notes, even if a state does not wish to go to this extreme and provide all levels of education without any fees, it should not create a financial barrier without any funding options for which all potential students can apply.

While it is the federal government's responsibility to ratify an international treaty, any level of government has the ability to implement it. In fact, even if the federal government has not yet ratified an agreement, provinces and/or municipalities can still move forward with establishing ways to fulfill its requirements. Martha F. Davis (2019) contends that "local governments" are already responsible for addressing matters regarding human rights, such as their constituents' access to food, water, shelter, and education (p. 268). Hence, provincial and municipal governments can "bypass the nation state to interact more directly than ever with international human rights systems, both as norm developers and norm implementers" (Davis, 2019, p. 268). As Davis implies, all levels of government can take on the responsibility to apply international law and ensure that efforts are being made to protect human rights.

Courts also have an important role to play. The general rule is that courts may use international law, including treaties and customary law, to interpret the Charter of Rights and Freedoms (PSERA, 1987; Slaight Communication, 1989). Courts may also interpret (ambiguous) statutes to cohere with international law unless a legislature has clearly indicated an intention to derogate from Canada's international obligations (Hudson, 2008). Courts regularly use international law in the field of immigration and refugee law, more so than almost any other public law field (Rado, 2018). Unfortunately, courts have not been as active with regards to economic and social rights. The Charter does not expressly contain such rights-it only offers civil and political rights. Courts have expressly declined to "read in" economic and social rights, although some judges (e.g. Justice Louise Arbour) have been prepared to recognize a right to social assistance (Jackman, 2019). Canada has also declined to sign the Optional Protocol to the ICESR, which would grant a treatymonitoring body to receive complaints and render judgment on Canada's compliance 1. Academics such as Martha Jackman, Bruce Porter, and Craig Scott have made compelling arguments for why economic and social rights can and ought to be justiciable within Canada (Jackman, 2019; Porter, 2016). Courts may yet adopt such reasoning in

1 We would like to thank Dr. Idil Atak for bringing this to our attention. 
some cases.

The human right to education legally applies to undocumented immigrants because it asserts that education must be granted to every individual residing within a state, without any prejudice towards one's personal characteristics -including national political or legal status. It determines that the state cannot decide who can and cannot obtain an education as this would be an infringement on a fundamental right. It is open to courts to use international law to ground this right in the Charter and even in statutes, such as public education legislation. A human rights theoretical framework is applied in this paper because it allows the reader to assess the issue of access to post-secondary education as a basic human right, rather than as a function only of national law or policy, possibly informing strategies for influencing positive state action. As UN Special Rapporteur and human rights lawyer Manfred Nowak (1991) aptly remarks, "[Education] is not only a kind of idealistic goal, ....but a legally binding human right of the majority of the present world population" (p. 425). The human right to education, along with the court rulings and international legislation passed on it, justifies the concern behind this ongoing issue and the need for it to be addressed.

\section{Overview of the Topic: Undocumented Immigrants}

\section{Statistics}

Based on figures from 2009, there are between 200,000 and 500,000 individuals living in Canada without legal status-totalling $0.5 \%$ to $1.3 \%$ of the national population (Meloni, Rousseau, Ricard-Guay, \& Hanley, 2017, p. 15). Approximately $25 \%$ of this population are minors. These statistics are not only a decade old, but they are not nearly as accurate as those obtained in other countries like the US. The information obtained through the US census is cross-referenced with other public records to calculate a more precise number. Meanwhile, Canada's number is a "guesstimate," leaving us with no reliable nor accurate figures regarding this portion of the population. In fact, the actual statistics may be even greater than the estimates made. Professors Lilian Magalhaes, Christine Carrasco, and Denise Gastaldo (2010), from the University of Western Ontario and UofT, stress this notion when they state,

In 2003, Ontario's Construction Secretariat purported that there were 76,000 nonstatus immigrants in Ontario's construction industry alone, while other sources confirmed that at least 36,000 failed refugee applicants had never been deported, and another 64,000 individuals overstayed their work, student or visitor visas in 2002. If it is assumed that workers are accompanied by family, the numbers in Ontario would rise to the highest figure previously estimated for all of Canada (p. 2).

Although this research is also dated, it emphasizes a key point: the nation-wide figures available today are inaccurate. It supports the argument that the current population of undocumented immigrants in Canada has not only been overlooked but has likely increased and exceeded the estimates made over ten years ago.

\section{Discussion on the Term "Illegal"}

There are diverse ways by which an individual can become undocumented, ranging from entering the country illegally through an unofficial border crossing to arriving legally and overstaying beyond a visa's expiration date (Wilson, 2009, p. 7; Simich et al., 2007, p. 369). The phrases "illegal immigrant" and "illegal alien" are commonly used to refer to 
individuals in these situations, who do not hold a secure status in their country of residence.

The term "illegal" holds substantial weight, evoking a negative connotation when referring to immigration. As the University of San Francisco asserts, "Illegal [is] a racially charged slur used to dehumanize and discriminate against immigrants and people of colour regardless of migratory status" (DACA and Undocumented Students, 2019). Thus, it is important to address this minority accurately, rather than using a term that suggests criminality and perpetuates a negative stigma against the group being discussed.

Nevertheless, "illegal" and "illegal alien" are commonly used in today's society as a political tool. Those opposed to providing undocumented immigrants with access to social human rights - such as education and health services-often use this terminology. This is done intentionally in order to frame this population as criminals. According to Robert $\mathrm{M}$. Entman (1993), "To frame is to select some aspects of a perceived reality and make them more salient in a communicating text, in such a way as to promote a particular problem definition, causal interpretation, moral evaluation, and/or treatment recommendation for the item described" (p. 52). Labelling undocumented immigrants as criminals results in society "automatically questioning their rights to access the benefits of society" (Jefferies, 2008 , p. 250). Therefore, framing undocumented immigrants in this negative light leads one to oppose accepting them and offering them assistance.

While the terminology and its implications are static, the individuals associated with this term are ever-changing. Alessandra Miklavcic (2011) discusses this situation, stating, "[I]llegal immigration has become a tangible social reality in countries such as the United States, the European Union, Canada, and Australia.... Yet illegality is a status that is not fixed[,] but contingent and unstable: it is produced and imposed within shifting relations of power" (p. 499). Essentially, being "illegal"-more accurately referred to as "undocumented"-is unique in that it is not a stagnant status. Rather, it can fluctuate following an election in which a new government-with views directly opposite to those of the previous administration-begins passing legislation that affects one's status in either a positive or negative way. The constant uncertainty and vulnerability that undocumented immigrants face juxtapose the unsympathetic negative connotation that "illegal immigrant" implies. Therefore, this terminology will no longer be mentioned in this paper; this marginalized group will be referred to as "undocumented" going forward.

\section{The Debate over Providing Access to Post-Secondary Education}

While Canadian legislation directly addressing undocumented immigrant minors' right to attend public school has been established, the issue regarding their ability to obtain a post-secondary education remains. Kera Wanielista and Daniel Demay (2014) describe the difficult position that this marginalized group is in when they write, "[U]ndocumented students graduate... each year, launching into a world where they face their first major challenge as an adult: surviving in a culture that protects children, no questions asked, but offers plenty of roadblocks once they reach adulthood." This opinion may be sympathetic towards undocumented immigrants, but it is not the sole viewpoint on the topic. On the contrary, there is a large divide between the two main stances on this issue, with strong assertions made on both sides.

The pro-immigrant camp makes both emotional and economic arguments in favour of providing undocumented students with access to post-secondary education. Often, they draw attention to hard-working, exemplary members of this group, emphasizing how they are "overcoming insurmountable odds" and that the negative connotation attributed to them is merely an inaccurate stereotype (Jefferies, 2008, p. 250). The pro-immigrant faction also asserts that not providing access to post-secondary education results in undocumented immigrants obtaining low-skilled jobs, thereby limiting their ability to 
improve their economic status in society (Jefferies, 2008, p. 249). Instead, they remain stagnant in the low-skilled, low-education demographic, which hinders their economic advancement and allows the negative stereotype allotted to this marginalized population to continue.

For those opposed to offering access to education, their reasoning revolves around taxation and its usage. A common argument is that the government collects taxes from citizens who are legally living and working in the country, yet must spend on providing services not only to citizens, but to undocumented immigrants who-unlike citizens-do not contribute. However, there is sufficient evidence that counters the claim that undocumented immigrants utilize services available to them without equitable contribution. The three main taxes that undocumented immigrants, alongside citizens, must pay are: sales tax, property tax, and income tax. There are various ways that undocumented immigrants contribute through income tax, including the use of false social insurance numbers for payroll or-in the case of the US-filing with Individual Tax Identification Numbers (ITINs). The latter is an option that the US Internal Revenue Service (IRS) created to allow individuals who are unlawfully working in the country to still be able to file taxes on their earnings. For obvious reasons, all three of these taxes are difficult, if not impossible, to avoid and consequently provide substantial fiscal earnings (Isbister, 1996, p. 154). Thus, using this argument to justify denying undocumented immigrants access to education can be easily invalidated.

This debate will likely persist as both sides have strong views and find it difficult to compromise their beliefs. Still, it is vital to relay factual, unbiased information regarding this issue so that an individual can assess the facts at hand and make a logical decision on his/her stance.

\section{Access Granted to Primary and Secondary Schools}

The issue regarding an individual's access to education is a difficult one to resolve as it stems from "a more profound ethical question: which [people] should have-or deserve-the right to [access it]" (Meloni et al., 2017, p. 16). This concept applies to all social services, including education, healthcare, housing, etc. Decisions made on this ethical question through court rulings and/or public policies either prevent or provide certain groups with access to these services. Canada addressed the issue of an undocumented immigrant's access to education and made respective legislative decisions regarding one's ability to obtain primary and secondary schooling. Although gaps still remain in terms of the effectiveness of this legislation, it is important to discuss the advances made in lower education levels relative to post-secondary education.

Canada passed the Immigration and Refugee Protection Act (IRPA; the Act) in 2001, to regulate immigration into the country. This document's focus is not on education but does briefly mention an immigrant minor's right to access schooling. Section 30(2) of the Act reads, "Every minor child in Canada, other than a child of a temporary resident not authorized to work or study, is authorized to study at the pre-school, primary or secondary level" (Immigration and Refugee Protection Act [IRPA], 2001).

Aside from this instruction given in the IRPA, Canada does not currently have any federal judicial or legislative statute that regulates a board of education's decisions on enrolment and access. Rather, provincial policies determine the provision or restriction of access to education. Provincial laws define the term "migrant" or "immigrant" relative to the IRPA, but are generally silent about status as a condition of enrollment. In British Columbia (BC), for example, Section 2(1) of the School Act provides access to all persons who are of "school age" and are "resident[s] in that school district" (1996). In some cases, a school's administration may agree to accept a student with certain conditions. The administration may require the minor's parents/guardians to pay a high tuition fee, or may 
allow the minor to attend classes without being officially enrolled in the Ministry of Education-resulting in the student not receiving a graduation diploma (Meloni et al., 2017, p. 18). These undocumented minors are considered to be "institutionally invisible," meaning that their access to education often involves "discretionary practices," which essentially construct the children as being excluded from school (Meloni et al., 2017, p. 15).

As a result, there is considerable variation within and between provinces. In $\mathrm{BC}$, for example, the New Westminster school district in BC passed an access without fear policy (New Westminster School Board, 2017). No other district has done so yet. Quebec also recently changed its policies. Until 2017, the province required any individual seeking to enrol themselves or their child in a public school to show proof that they have legal status in Canada-whether it be as a Canadian citizen, asylum seeker, foreign worker, etc. (Meloni et al., 2017, p. 16). If they were unable to provide this information, then they would not be able to enroll in public school. Under Bill 144 (Assented to 9 November 2017), the law no longer requires proof of status; it applies to all children of age who satisfy certain residency requirements. However, Quebec's law falls short of a policy of access, and will likely lead to the same variations that we see in other provinces as a function of the discretion of local boards and schools.

Overall, the lack of clear laws on how public-school institutions should address undocumented immigrants has put this marginalized group in a very precarious situation regarding access to education. To that end, the Toronto District School Board realized that it needed to address this issue at the municipal level. Even though Ontario passed the Education Act in 1990, the province left the task of establishing directives based on this legislation to the school districts. In 2007, the Toronto District School Board passed the Students Without Legal Immigration Status Policy, which prohibits schools from inquiring about a potential student's status; it allows minors to attend primary and secondary schools regardless of their immigration status. Commonly referred to as the "Don't Ask, Don't Tell" (DADT) policy, it asserts, "All children who are qualified to be resident pupils of the Board, including those who are without immigration status in Canada, shall be entitled to admission to school. All children shall be welcomed, regardless of immigration status, and information about them or their families shall not be shared with Immigration authorities" (Toronto District School Board, 2007).

While some may consider the DADT legislation to be a ground-breaking step forward in Canada, others critique the various shortcomings regarding its implementation ( $F$. Villegas, 2018). Francisco Villegas (2014) argues that denial of access is driven by neoliberal logics and fiscal constraints, which present incentives to deny access to nonstatus migrants. The DADT policy is a limited success and flaws may still exist, but it is important to highlight the policy as it directly addresses the matter of providing access to education for undocumented immigrants.

\section{Barriers to Accessing Post-Secondary Education in Ontario, Canada}

While there may not be federal or provincial laws in Canada that directly prohibit undocumented immigrants from attending post-secondary institutions, there certainly are distinct aspects of the post-secondary application and enrolment process that pose an issue. The most prominent obstacles are procedural hindrances and financial burdens. Specifically, the barriers that could obstruct undocumented students from continuing into higher level education in Ontario will be assessed from a procedural and financial perspective. 


\section{Procedural Barriers}

In the province of Ontario, students use the Ontario Universities Application Centre (OUAC) and the Ontario College Application Service (OCAS) to submit their applications for post-secondary studies. These systems may have been established to provide a uniform, streamlined method to submit one's application to various institutions all at once, but they still have shortcomings when evaluating accessibility. As Aberman and Ackerman (2017) astutely remark, "These centres act as the first gatekeepers, requesting that immigration status be acknowledged immediately" (p. 132). Both OUAC and OCAS require the applicant to disclose their current status in Canada in order to complete the application. The centres offer the option to select "Other: No Status," implying that the centres would allow an individual without legal status in Canada to apply, so long as they disclose it. Based on correspondence with the Manager of Processing-Undergraduate Programs at OUAC, Wilson (2009) confirms that the centre does not require the applicant to submit any supporting documents as proof of their legal status (p. 19). Rather, OUAC processes all completed applications regardless of their current status in Canada.

However, while Ontario's online application centres claim to keep this information private and not accessible to authorities, undocumented students may still be hesitant to disclose their status. OUAC's Declaration and Notice of Collection, Use, Disclosure and Treatment of Personal Information states, "We and/or the universities notify universities and colleges across Canada and/or other regulatory authorities (e.g., Canadian Border Services Agency [CBSA]), at our absolute discretion..." (OUAC, 2010). Mentioned in the lengthy privacy agreement that a student must accept prior to having their application officially submitted, this declaration may further discourage an undocumented student from applying through these channels. Indeed, OUAC claims that this would only be necessary if the centre suspects an application to be "false, misleading, or if it contains evidence of academic dishonesty or inappropriate or unethical conduct" (OUAC, 2010). Yet, someone in a precarious situation may not risk applying for fear of their status being disclosed to the CBSA, should the processing centre believe that something in their application is invalid for some reason.

Overall, the OUAC and OCAS applications' sole question that inquires about one's legal status could deter undocumented immigrants from applying, thereby limiting their access to obtaining higher education. To that end, although these centres are relatively lenient towards non-status applicants, they do not ensure that other barriers will not arise between applying and enrolling in a post-secondary program.

\section{Financial Barriers}

Should an undocumented immigrant apply through OUAC or OCAS and get accepted to a post-secondary institution, it is customary for the university or college to request the individual's Social Insurance Number (SIN) in order to confirm that the student is eligible for domestic tuition fees. On the contrary, if one does not provide this information, the individual would be considered an international student; they would need to obtain the visa necessary for them to legally study in Canada as well as pay international student tuition fees (Wilson, 2009, p. 21).

It is common practice for eligible students to apply for government funding to assist them in paying their post-secondary tuition and various school-related expenses. In Ontario, the Ontario Student Assistance Program (OSAP) assesses students' applications to determine how much financial aid they will be given. On average, graduates of fouryear university programs receive $\$ 21,515$ in loans; two-year college graduates receive $\$ 12,393$ (Ontario Training, Colleges and Universities, 2014). These amounts do not include the non-repayable grants often awarded to students as well. To put it in 
perspective, the University of Toronto (UofT) gathered data regarding its student body's financial support and found that approximately $46 \%$ of its full-time domestic students obtain financial aid from OSAP annually to help cover their tuition fees (Office of the ViceProvost, 2018). These statistics emphasize how pivotal governmental aid is in providing potential students with the funding necessary for them to pursue higher education.

Unfortunately for undocumented immigrants, the Canadian Student Financial Assistance Act states that "only persons with citizenship, permanent resident, or Protected Person status qualify for government student loans," thereby denying the ability for nonstatus individuals to access public financial support (Wilson, 2009, p. 24). Although not as commonly used as OSAP to fund academia, another potential lender is the bank. However, individuals are only able to apply for a bank loan if they are Canadian permanent residents or citizens (Wilson, 2009, p. 25). Thus, the only remaining option for this marginalized group is to be admitted as an international student and be charged international student fees.

While the pathway to accessing post-secondary education as an international student may appear feasible, it certainly poses obstacles for the undocumented student wishing to attend. Firstly, the process of getting a valid student visa-a requirement for registration in all post-secondary institutions-is challenging, as one must apply for a study permit from outside Canada. The Government of Canada's official website outlines the specifications, prohibiting almost everyone from attaining a study permit within Canada, aside from a select few circumstances (e.g. the individual applying, the individual's spouse/partner, or their parent already has a valid study or work permit) (Citizenship Canada, 2019a). The list of individuals who may be able to apply for a study permit from inside Canada also includes "a minor child in primary or secondary school" (Citizenship Canada, 2019a). However, there is no detailed information as to how an applicant who falls under this particular category-and is also undocumented-could apply for a postsecondary study permit while residing within Canada's borders. Rather, the Application Guide solely focuses on minors who wish to attend Canadian primary or secondary schools (Citizenship Canada, 2019b). In short, aside from a few exceptions, the Canadian government requires everyone who is not a permanent resident or citizen to apply for a study permit in order to legally attend a Canadian institution.

There is a mandatory $\$ 150$ fee that one must pay to have their study permit application processed, but this is a trivial expense relative to the international student tuition fees that would follow-should the visa be granted. Based on the 2018-2019 academic year, Canada's international undergraduate tuition average $(\$ 27,159)$ is nearly four times greater than the average domestic tuition $(\$ 6,838)$ (Statistics Canada, 2019). Since this paper is focussing on Ontario, it is important to note this province's tuition fees as well: international undergraduate tuition average is $\$ 34,961$, and domestic undergraduate tuition is $\$ 8,838$ (Statistics Canada, 2019). While the percentage gap between international and domestic tuition fees in Ontario matches that of the Canadian average, the difference in monetary amounts is significantly larger in Ontario.

As statistics clearly show, Canadian international student tuition is considerably higher than domestic student tuition. Not only would an undocumented immigrant need to finance their post-secondary education without governmental assistance, but they would need four times more funds to do so. The significant disparity between students with legal status and non-status students regarding post-secondary financial support in Ontario-and Canada as a whole-is evident. Although some may argue that there is no feasible solution for this concern, certain Canadian university policies show that successful efforts can be made to reduce these existing barriers. 


\section{The Canadian Initiative}

Canadian governmental bodies have yet to pass any official legislation regarding access to higher education for undocumented immigrants. As for Canadian postsecondary institutions, however, some universities are attempting to reduce the obstacles currently facing undocumented immigrants who wish to pursue post-secondary studies. Ontario universities' respective boards of governors have substantial autonomy over academic and administrative concerns; therefore, they have the ability to lift barriers to access (Wilson, 2009, p. 18). The efforts being made in two of Canada's largest universities, York University and the University of Toronto, will be addressed in this chapter.

\section{York University Pilot Program}

In January 2017, York University (YorkU) began a pilot project that allowed ten individuals who had a precarious immigration status to enrol for an undergraduate degree (P. Villegas \& Aberman, 2019, p. 77; Wiens, 2018). Referred to as the Access for Students with Precarious Immigration Status (ASPIS) program, it is the first of its kind to be initiated in a Canadian post-secondary institution (P. Villegas \& Aberman, 2019, p. 76). The YorkU webpage describes it as "academic bridging ... for students who have precarious immigration status (including no status) and have faced barriers accessing post-secondary studies as a result" (York University Department of Sociology, 2018).

The program provides two options for prospective undocumented students: (1) a direct entry into the undergraduate program of their choice, provided they are academically capable and mentally prepared to start straight away; or (2) enrolment in a bridging course that focuses on migration studies (e.g. global migration, migrants' inequality, etc.) to introduce the student to post-secondary level expectations (P. Villegas \& Aberman, 2019, p. 77). The latter pathway not only aims to provide undocumented immigrants with a smooth transition into a full-time undergraduate program of their choice but also offers a safe space for this marginalized portion of the student body. Often, undocumented immigrants do not disclose their status to others for fear of what the outcome may be (Working Group on Access, n.d.[a]). YorkU's Bridging program allows for students to connect with others who are in similar challenging situations, reducing the isolation that they may feel (P. Villegas \& Aberman, 2019, p. 77).

In the program's first year, YorkU President Rhonda Lenton stated that the university aimed to expand access to education over the next five years. YorkU's pilot project was initially funded by the Toronto municipal government, through a Pan Am Games grant that is awarded to initiatives that aim "to improve equity, access and human rights" (Wiens, 2018). The City of Toronto's financial support only lasted three months; it was up to YorkU to acquire the necessary funds to continue the program-should it wish to do so. Currently, the program is in its third academic year and has expanded through support from various donors. As of 2018, 28 students successfully completed the Bridging program, 12 students were already enrolled in full-time undergraduate studies, and 20 additional students had been accepted for the 2018-2019 school year (Working Group on Access, n.d.[a]).

In addition to providing access, Lenton also understands that tuition fees will need to be addressed since domestic fees are far more affordable than international fees (Wiens, 2018). Prior to the ASPIS program, undocumented immigrants wishing to pursue higher education at YorkU had to enrol as international students and be charged international fees. Now, individuals enrolled in this particular program are offered domestic tuition rates.

Unfortunately, due to various procedural barriers discussed earlier in this paper, undocumented students are unlikely to obtain financial aid from OSAP to help cover their fees. In an attempt to lessen the gap between expenses and available funding, YorkU's 
Centre for Refugee Studies (CRS) established the Refugee Student Bursary, which specifically supports students who are refugees or undocumented (York University, n.d.). To be fair, this bursary is the only grant that an undocumented perspective YorkU student is eligible for and does not offer as much support as could be provided through government-funded aid. However, regarding the CRS Refugee Student Bursary and the YorkU ASPIS program overall, one must admit that-at the very least-these are tangible efforts made towards reducing the barriers currently in place against undocumented immigrants who wish to access Canadian post-secondary education.

\section{University of Toronto Proposal}

Meric Gertler, President of the UofT, claims that the university has "the most generous and comprehensive access guarantee in the country" (Working Group on Access, n.d.[b]). While this assertion can be debated, the university has assembled a group to look into providing undocumented immigrants with better access to post-secondary education. Entitled "The Working Group on Access to Higher Education for Students with Precarious Immigration Status" (referred to as the "Working Group" going forward), it is a collaborative effort that involves UofT faculty, staff, and students. The group's primary goal is to create policies that lessen the existing barriers to higher education.

In 2018, the Working Group presented a proposal for a pilot program to be established at the UofT. This program is largely based on the similar ASPIS Bridging program already in place at YorkU. Since the UofT already has the Transitional Year Program and the Academic Bridging Program in place, the proposal argues, "[By] building off their learnings and toolkits, the UofT can effectively launch a program for students with precarious immigration status and ensure the students' success" (Working Group on Access, n.d.[a]). In addition to the pro-access bridging program, the Working Group also addresses the tuition fee issue. Referencing the YorkU policy, the proposal recommends for undocumented students accepted into the UofT program not to be asked for proof of status or a study permit, but to be charged domestic rates rather than international rates (Working Group on Access, n.d.[a]).

The UofT Working Group also wants to ensure that undocumented students can attend classes safely, without fear of being apprehended by immigration officers. They suggest that the UofT implements an 'Access Without Fear' policy, which would allow students to access services (e.g. obtaining a UofT Student Card) without first being required to prove their legal status (Working Group on Access, n.d.[a]). Moreover, they advise the UofT to deny access to the campus for CBSA officers, unless the university is notified ahead of time or if it is an "extreme circumstance" (Working Group on Access, n.d.[a]; Working Group on Access, n.d.[b]). These measures would help provide a more secure environment for students who may otherwise hesitate to attend class due to a sense of insecurity.

The Working Group proposal cites various UofT policy documents, which state that one of the university's goals is to establish an "equitable and inclusive community" (Working Group on Access, n.d.[a]). The proposal argues that the university is falling short of achieving this objective as it denies equal access to undocumented students who wish to pursue higher education (Working Group on Access, n.d.[a]). In order to remove these barriers, the Working Group (n.d.[a]) insists, "The UofT should create a program that will allow academically-qualified residents with precarious immigration status to apply and attend university safely and affordably." While this proposal for a pilot program is still in its early stages, it is important to highlight the steps that the UofT is taking towards improving access to post-secondary education. As the UofT proposal often refers to the existing YorkU program, this demonstrates how a university's ambitious goal can be accomplished and then lead to other institutions using these successes as a framework to establish 
similar policies.

\section{Conclusion}

The undocumented immigrant topic has been a hot-button issue in the US for decades and continues to be a polarizing issue today. A reason for this may be because of the lengthy southern US border with Mexico, which anti-immigrant factions often refer to when arguing against providing access to so-called "illegal aliens." Meanwhile, Canadian media and politicians do not focus on this portion of our population as frequently. Rather, it only comes to the forefront when Canada faces a crisis, such as sudden unauthorized entry or asylum claims on a large scale (Goldring, Berinstein, \& Bernhard, 2009, pp. 245-246). Although this disregard may appear as beneficial for undocumented immigrants who wish to remain under the radar, it also creates barriers against accessing social human rightsparticularly education. Indeed, Canadian statutes that provide primary and secondary schooling to all minors regardless of their legal status have been established but are not reliably accessible. Upon graduating from secondary school, an undocumented student has limited options to continue their education. Instead of being offered opportunities, they are likely to face various roadblocks.

Barriers limit the availability of a service on the basis of one's immigration status. Undocumented immigrants encounter various challenges when applying to postsecondary institutions in Canada; while there are currently no provincial or federal laws that prohibit post-secondary schools from accepting undocumented students, applicants must overcome various procedural obstacles and financial burdens.

Post-secondary institutions have enough autonomy to lift certain barriers that are currently in place. As Paloma E. Villegas and Tanya Aberman (2019) advise, "Universities and colleges across Canada can also adopt inclusionary practices to counter their presence as racialized and immigration status centred sites, to reduce the barriers that prevent certain students from following their dreams" (p. 79). YorkU's ASPIS Bridging program and the UofT's program proposal are clear examples of such initiatives currently taking place. To be fair, it is always best to assess an initiative through a critical lens to see where further advancements are possible. In YorkU's case, the ASPIS program solely applies to students looking to access undergraduate programs. If a student who enrolled in YorkU through the ASPIS program wishes to pursue post-graduate studies-a master's degree or PhD - they would be restricted yet again. Perhaps the next step at YorkU would be to expand this program to all levels of higher education.

In the Canadian context, undocumented immigrants tend to get overlooked, but they are undeniably present. Hence, this marginalized group must be acknowledged and granted the social human rights to which they are entitled. Both governmental and nongovernmental institutions should abide by domestic and international laws; they should increase efforts to provide non-status residents with access to all levels of schoolingincluding post-secondary education.

Canada has acknowledged the social human right to education in several international treaties, yet (in)direct barriers still remain. This paper's findings highlight the efforts being made to provide more individuals with access to this human right. However, these are not federal nor provincial policies; gaps and barriers to access still remain depending on where the undocumented immigrant lives. Although Canada has ratified the ICESCR, the federal government has yet to pass any law that enforces the requirements outlined in the treaty. Provincial and municipal institutions, as well as courts, also have a responsibility to ensure that international agreements are implemented. Whether it is enforced through a top-down or bottom-up approach, the social human right to (post-secondary) education has to be accessible to everyone, regardless of their legal status. 


\section{References}

Aberman, T., \& Ackerman, P. (2017). Isn't the right to an education a human right? In Sara Carpenter \& Shahrzad Mojab (Eds.), Youth as/in crisis: Young people, Public Policy, and the Politics of Learning (pp. 127-144). Sense.

Andrews v. Law Society of British Columbia. (1989). 1 S.C.R. 143. Retrieved from https://scc-csc.lexum.com/scc-csc/scc-csc/en/item/407/index.do

Canadian Charter of Rights and Freedoms, s 15, Part I of the Constitution Act, 1982, being Schedule B to the Canada Act 1982 (UK), 1982, c11.

Citizenship Canada. (2019a, June 4). Study permit: How to apply. Retrieved on June 30, 2019 from https://www.canada.ca/en/immigration-refugees-citizenship/services/studycanada/study-permit/apply.html

Citizenship Canada. (2019b, June 12). Guide 5552 - Applying to change conditions or extend your stay in Canada - student - online application. Retrieved on June 30, 2019 from https://www.canada.ca/en/immigration-refugeescitizenship/services/application/application-forms-guides/guide-5552-applyingchange-conditions-extend-your-stay-canada-student.html

Crépeau, F., Nakache, D., \& Atak, I. (2007). International migration: Security concerns and human rights standards. Transcultural Psychiatry, 44(3), 311-337.

DACA and Undocumented Students. (2019, February 18). Retrieved from https://www.usfca.edu/education/admission-and-aid/undocumented-students

Davis, M. F. (2019). Scoping the new urban human rights agenda. The Journal of Legal Pluralism and Unofficial Law, 51(2), 260-270.

Entman, R. M. (1993). Framing: Toward clarification of a fractured paradigm. Journal of Communication, 43(4), 51-58.

Gavison, R. (2003). On the relationships between civil and political rights, and social and economic rights. In J. Coicaud, M.W. Doyle, \& A. Gardner (Eds.), The globalization of human rights (pp. 23-55). New York, NY: United Nations University Press.

Goldring, L., Berinstein, C., \& Bernhard, J. K. (2009). Institutionalizing precarious migratory status in Canada. Citizenship Studies, 13(3), 239-265.

Hudson, G. (2008). Neither here nor there: The (non-) impact of international law on judicial reasoning in Canada and South Africa. Canadian Journal of Law \& Jurisprudence, 21(2), 321-354.

Immigration and Refugee Protection Act (IRPA) [Canada], SC 2001, c. 27, 1 November 2001. Retrieved from https://laws-lois.justice.gc.ca/eng/acts/i-2.5/FullText.html

Isbister, J. (1996). The immigration debate: remaking America. West Hartford, CT: Kumarian Press.

Jackman, M. (2019). One step forward and two steps back: Poverty, the charter and the legacy of gosselin. National Journal of Constitutional Law, 39(1), 85-121. Retrieved from http://ezproxy.lib.ryerson.ca/login?url=https://search-proquestcom.ezproxy.lib.ryerson.ca/docview/2171578102?accountid=13631

Jefferies, J. (2008). Do undocumented students "play by the rules"? Journal of Adolescent \& Adult Literacy, 52(3), 249-251.

Kalantry, S., Getgen, J., \& Koh, S. (2010). Enhancing enforcement of economic, social, and cultural rights using indicators: A focus on the right to education in the ICESCR. Human Rights Quarterly, 32(2), 253-310.

Magalhaes, L., Carrasco, C., \& Gastaldo, D. (2010). Undocumented migrants in Canada: a scope literature review on health, access to services, and working conditions. Journal of Immigrant and Minority Health, 12(1), 132-151.

Meloni, F., Rousseau, C., Ricard-Guay, A., \& Hanley, J. (2017). Invisible students: Institutional invisibility and access to education for undocumented children. International Journal of Migration, Health and Social Care, 13(1), 15-25.

Miklavcic, A. (2011). Canada's non-status immigrants: Negotiating access to health care 
and citizenship. Medical Anthropology, 30(5), 496-517.

Nowak, M. (1991). The right to education - Its meaning, significance and limitations. Netherlands Quarterly of Human Rights, 9(4), 418-425.

New Westminster School Board. (2017, March 7). First in BC - School Board Adopts Sanctuary Schools Policy. Retrieved from https://newwestschools.ca/first-in-bcschool-board-adopts-sanctuary-schools-policy/.

Office of the Vice-Provost, Students. (2018, March 12). Annual Report on Student Financial Support, 2016-17. Retrieved from https://www.provost.utoronto.ca/wpcontent/uploads/sites/155/2018/05/Annual-Report-Student-Financial-Support-201617.pdf

Ontario Training, Colleges and Universities. (2014, April 25). Average OSAP Debt. Retrieved from https://www.ontario.ca/data/average-osap-debt

Ontario Universities' Application Centre (OUAC). (2010, June 18). OUAC 101 Declaration and Notice. Retrieved from https://www.ouac.on.ca/privacy/101declaration/

Porter, B. (2019, June 20). Social policy and social rights in Canada: historical reflections [PDF file]. The Philanthropist. Retrieved from https://thephilanthropist.ca/2016/06/social-policy-and-social-rights-in-canadahistorical-reflections/

(PSERA) Reference Re Public Service Employee Relations Act (Alta.), [1987] 1 S.C.R. 313.

Rado, K. (2018). The transnational judicial dialogue of the Supreme Court of Canada and its impact (Unpublished doctoral dissertation). York University, Toronto.

Retrieved from https://digitalcommons.osgoode.yorku.ca/phd/40/

School Act, RSBC 1996, c 412.

Simich, L., Wu, F., \& Nerad, S. (2007). Status and health security: An exploratory study of irregular immigrants in Toronto. Canadian Journal of Public Health, 98(5), 369-73.

Slaight Communications Inc. v. Davidson, [1989] 1 S.C.R. 1038.

Statistics Canada. (2019, July 22). Canadian and international tuition fees by level of study. Retrieved from https://www150.statcan.gc.ca/t1/tbl1/en/tv.action?pid=3710004501

Toronto District School Board. (2007, May 16). Summary of decisions regular meeting [PDF file]. Retrieved from https://www.tdsb.on.ca/Leadership/Boardroom/AgendaMinutes/Type/M/Year/2007?Filename=70516.pdf

Toussaint v. Canada (Attorney General), 2011 FCA 213, CanLII.

UN Commission on Human Rights, The right to education: Report submitted by Katarina Tomasevski, Special Rapporteur: Addendum Mission to Colombia, 15 January 2004, E/CN.4/2004/45. Retrieved from https://documents-ddsny.un.org/doc/UNDOC/GEN/G04/103/32/PDF/G0410332.pdf?OpenElement

UN Committee on Economic, Social and Cultural Rights (CESCR), General Comment No. 13: The Right to Education (Art. 13 of the Covenant), 8 December 1999, E/C.12/1999/10. Retrieved from https://www.refworld.org/docid/4538838c22.html

UN General Assembly, International Covenant on Economic, Social and Cultural Rights, 16 December 1966, United Nations, Treaty Series, vol. 993, p. 3. Retrieved from https://treaties.un.org/doc/Treaties/1976/01/19760103\%200957\%20PM/Ch_IV_03.pdf

UN General Assembly. (n.d.). Status of Signatories Chapter IV Human Rights. Retrieved from https://treaties.un.org/Pages/ViewDetails.aspx?src=IND\&mtdsg_no=IV$3 \&$ chapter $=4 \&$ clang $=$ en

Villegas, F. J. (2018). 'Don't ask, don't tell': Examining the illegalization of undocumented students in Toronto, Canada. British Journal of Sociology of Education, 39(8), 1111- 
1125.

Villegas, F. J. (2014). The politics of "access": Undocumented students and enrollment in Toronto schools (Unpublished doctoral dissertation). University of Toronto, Toronto.

Retrieved from https://tspace.library.utoronto.ca/bitstream/1807/68161/1/Villegas_Francisco_J_2014 11_PhD_thesis.pdf

Villegas, P. E., \& Aberman, T. (2019). A double punishment: The context of postsecondary access for racialized precarious status migrant students in Toronto, Canada. Refuge: Canada's Journal on Refugees, 35(1), 72-82.

Wanielista, K., \& Demay, D. (2014, August 31). A path to nowhere. TCA Regional News. Retrieved from http://ezproxy.lib.ryerson.ca/login?url=https://search-proquestcom.ezproxy.lib.ryerson.ca/docview/1558519525?accountid=13631

Wiens, M. (2018, January 15). York first Canadian university to give 'Dreamers' a chance at a degree. CBS News. Retrieved from https://www.cbc.ca/news/canada/toronto/canadian-dreamers-york-university1.4488252

Wilson. M. (2009). Access to postsecondary education for undocumented immigrants [PDF file]. Retrieved from https://we.riseup.net/assets/17110/WilsonMLawReformPAPER1_pdf.pdf

Working Group on Access to Higher Education for Students with Precarious Immigration Status, University of Toronto. (n.d.[a]). Position Paper - Access for students with precarious immigration status: Proposal for a pilot program at the University of Toronto (UofT). Unpublished manuscript.

Working Group on Access to Higher Education for Students with Precarious Immigration Status, University of Toronto. (n.d.[b]). Removing barriers: A fact sheet on access to education in Canada for students with precarious immigration status. Unpublished manuscript.

York University. (n.d.). Centre for Refugee Studies. Retrieved from https://crs.info.yorku.ca/

York University Department of Sociology. (2018). Options for Students with Precarious Immigration Status. Retrieved from http://soci.laps.yorku.ca/dreamers/ 